\title{
KARAKTERISTIK KAUM MUDA PADA PASAR TENAGA KERJA DAN DETERMINAN NEET DI INDONESIA
}

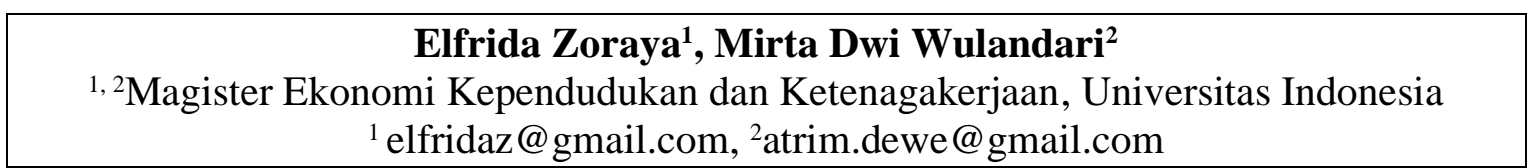
Diterima: Februari 2020; Disetujui: April 2020

Abstract. In Indonesia, young people are, according to BPS-Statistics Indonesia, almost one-fifth of the total population. Despite increasing general emphasis on youth employment, there is still an alarming issue from unemployment among youth since it was very high and likely to increase further. Recent Indonesia labour force survey shows that youth unemployment is $19.7 \%$ in 2018, while the rate of NEET young people reached $22.1 \%$. For this study will be analyzed several indicators like youth vulnerability in labor market, unemployment rate, and NEET. This study identify how youth unemployment and the NEET proportion in Indonesia. This study uses logistic binary analysis methods using SAKERNAS 2018 data to identify the determinants of NEET. The results obtained are social and demographic characteristics affecting young people to become NEET.

Keywords: neet, school-to-work transition, youth, youth unemployment rate.

Abstraksi. Menurut Badan Pusat Statistik (BPS), jumlah penduduk muda di Indonesia adalah hampir seperlima dari total penduduk. Meskipun terdapat peningkatan pada pekerja kaum muda , masih terdapat masalah yang mengkhawatirkan yaitu pengangguran di kalangan kaum muda, yaitu jumlah yang sangat tinggi dan terdapat kemungkinan jumlah ini akan bertambah setiap tahunnya. SAKERNAS 2018 menunjukkan pengangguran kaum muda sebesar 19,7\%, dan tingkat NEET penduduk muda mencapai 22,1\%. Penelitian ini mengidentifikasi karakteristik pengangguran kaum muda dan NEET di Indonesia. Penelitian ini menggunakan metode analisis binari logistik dengan menggunakan data SAKERNAS 2018 untuk mengidentifikasi determinan dari NEET. Hasil yang didapat adalah karakteristik sosial dan demografi mempengaruhi penduduk muda untuk menjadi NEET.

Kata Kunci: kaum muda, neet, pengangguran kaum muda, transisi sekolah-pekerjaan.

\section{PENDAHULUAN}

United Nation (UN) mendefinisikan kelompok usia 10 hingga 19 tahun sebagai remaja (adolescent) dan kelompok usia 1524 didefinisikan sebagai kaum muda (youth). International Labour Organization (ILO) mengadopsi definisi yang sama untuk menjelaskan rentang usia kaum muda, yaitu 15-24 tahun. Selain sebagai kekuatan dalam pembangunan, keamanan, dan keselamatan suatu negara di masa depan, kaum muda juga merepresentasikan sebagian dari populasi yang penuh dengan semangat, ide, inovasi dan pandangan terhadap masa depan.
Indonesia memiliki struktur penduduk muda, pada tahun 2018, lebih dari setengah populasi penduduk berusia di bawah 30 tahun dengan persentase kaum muda sebesar 16,6\% dari seluruh penduduk (BPS, 2013). Tahun yang sama, terdapat sekitar 20,8 juta penduduk 15-24 tahun yang merupakan angkatan kerja atau aktif secara ekonomi (economically active). Besarnya jumlah kaum muda dalam angkatan kerja ini setara dengan 15,9 persen dari total 131 juta penduduk usia 15 tahun ke atas yang merupakan angkatan kerja (Tabel.1). 
Tabel 1.

Status Ketenagakerjaan Kaum Muda Indonesia, 2018

\begin{tabular}{|c|c|c|c|c|c|c|c|}
\hline \multirow{3}{*}{$\begin{array}{c}\text { Kelompok } \\
\text { Populasi }\end{array}$} & \multicolumn{5}{|c|}{ Status Ketenagakerjaan } & \multicolumn{2}{|c|}{ Ringkasan Indikator } \\
\hline & \multicolumn{3}{|c|}{ Angkatan kerja } & \multirow{2}{*}{$\begin{array}{c}\text { Bukan } \\
\text { Angkatan } \\
\text { Kerja }\end{array}$} & \multirow{2}{*}{$\begin{array}{c}\text { Total } \\
\text { Populasi }\end{array}$} & \multirow{2}{*}{ TPAK } & \multirow{2}{*}{ TPT } \\
\hline & Bekerja & Menganggur & Total & & & & \\
\hline \multicolumn{8}{|l|}{$\begin{array}{c}\text { Kelompok } \\
\text { Umur }\end{array}$} \\
\hline $15-19$ & $4,535,840$ & $1,649,868$ & $6,185,708$ & $15,967,854$ & $22,153,562$ & 27.92 & 26.67 \\
\hline $20-24$ & $12,193,700$ & $2,450,407$ & $14,644,107$ & $7,172,977$ & $21,817,084$ & 67.12 & 16.73 \\
\hline Total & $16,729,540$ & $4,100,275$ & $20,829,815$ & $23,140,831$ & $43,970,646$ & 47.37 & 19.68 \\
\hline \multicolumn{8}{|l|}{$\begin{array}{c}\text { Jenis } \\
\text { Kelamin }\end{array}$} \\
\hline Laki-laki & $10,251,595$ & $2,470,250$ & $12,721,845$ & $9,730,021$ & $22,451,866$ & 56.66 & 19.42 \\
\hline Perempuan & $6,477,945$ & $1,630,025$ & $8,107,970$ & $13,410,810$ & $21,518,780$ & 37.68 & 20.10 \\
\hline $\begin{array}{c}\text { Total } \\
\text { Populasi 15+ }\end{array}$ & $124,004,950$ & $7,000,691$ & $131,005,641$ & $63,773,800$ & $194,779,441$ & 67.26 & 5.34 \\
\hline
\end{tabular}

Sumber : SAKERNAS 2018, (Data diolah).

Rentang usia 15-24 tahun, kaum muda umumnya masih bersekolah hingga lulus jenjang perguruan tinggi, tetapi sebagian di antaranya tidak melanjutkan sekolah ke jenjang lebih tinggi dan masuk ke pasar kerja. Kesempatan kerja bagi kaum muda merupakan hal yang penting terutama karena berada pada usia dimulainya produktivitas seseorang selama rentang hidupnya. Transisi dari pendidikan ke bekerja merupakan salah satu isu yang terkait dengan kaum muda.

Menurut ILO (2017), transisi sekolah ke pasar kerja sukses dilalui dengan ditandai oleh kaum muda memperoleh pekerjaan layak (decent work) dan memuaskan, sehingga dapat menurunkan tingkat kemiskinan.

Proses mencari pekerjaan bagi kaum muda bukanlah sesuatu yang mudah, dan merupakan langkah penting awal terintegrasinya kaum muda dengan masyarakat. Kesuksesan kaum muda dalam hal ini merupakan cermin dari kualitas pendidikan yang membekali kompetensi yang memadai untuk masuk ke pasar kerja. Pendidikan yang baik akan menuntun pada pekerjaan dan posisi yang baik dalam pasar kerja (Martin, 2009).

Tingginya angka pengangguran kaum muda adalah fenomena umum yang terjadi di seluruh dunia termasuk di Indonesia. Pada skala global, tingkat pengangguran kaum muda pada tahun 2017 adalah 13.1\%, sedangkan di Indonesia jauh lebih tinggi yaitu 20.4\% (ILO, 2017a). Sebagian pengangguran muda didominasi oleh lakilaki dalam rentang usia 20-24 tahun (Tabel 1). Selain karena tersedia supply tenaga kerja dari kaum muda karena proporsi penduduk muda yang besar dan terbatasnya lapangan 
pekerjaan, keterbatasan pengalaman bekerja pada pekerja muda adalah salah satu faktor yang menyumbang pada tingginya angka pengangguran kaum muda.

Menjadi pengangguran dalam jangka panjang dapat membuat tekanan pada individu, termasuk tekanan ekonomi. Anakanak yang menganggur dalam waktu yang cukup lama dapat meninggalkan luka yang dalam pada dirinya dan masyarakat (Adioetomo \& Indrayanti, 2016).

Belum terserapnya atau belum dimanfaatkannya pemuda yang tidak bekerja ataupun bersekolah dalam pasar kerja tercermin dalam indikator NEET (not in employment, education or training). Proporsi NEET pada tahun 2016 di Indonesia relatif tinggi, yaitu 23,2 persen, dan merupakan salah satu yang tertinggi di kawasan Asia (ILO, 2017a). Indikator ini tidak hanya mengelompokkan pemuda yang tidak bekerja, belajar atau menempuh pendidikan, dan mengikuti pelatihan, tetapi juga pemuda yang enggan bekerja atau tidak aktif mencari pekerjaan, termasuk yang pernah mencari pekerjaan sebelumnya. NEET menjadi perhatian dunia internasional dan merupakan salah satu tujuan dalam SDGs (Goal 8.8), yaitu hingga tahun 2030, mengurangi secara proporsional usia muda yang tidak bekerja, tidak menempuh pendidikan atau pelatihan.

Tingginya tingkat pengangguran maupun NEET dapat menyebabkan konsekuensi baik pada level individu maupun masyarakat, dalam jangka pendek maupun jangka panjang. Konsekuensi atau akibat ini dapat berupa isolasi secara finansial maupun sosial, kemiskinan dan degradasi fisik (Bălan, 2015). Penelitian yang dilakukan Feng et al. (2015) di Scotlandia, menemukan bahwa NEET pada usia muda memiliki resiko 2,8 kali lebih besar untuk menganggur atau tidak aktif secara ekonomi 10 tahun kemudian. Selain itu, kaum muda yang tergolong NEET juga memiliki resiko kesehatan fisik dan mental yang buruk 10 hingga 20 tahun mendatang.

Berdasarkan fenomena NEET yang terus meluas dan dampak negatifnya, penelitian ini mengkaji karakteristik kaum muda yang masuk ke dalam NEET dan faktor-faktor yang mempengaruhinya. Kaum muda yang digunakan dalam penelitian ini terbatas pada usia 15 hingga 24 tahun, sedangkan determinan NEET terbatas dilihat dari karakteristik sosial demografis.

\section{Tinjauan Pustaka}

Pengangguran pada kaum muda dapat terkait pada isu-isu lain seperti transisi dari sekolah ke pekerjaan, pekerjaan informal, mobilitas eksternal, brain drain, segmentasi, dan ketidakadilan dalam pemberian upah (Vasile, 2011). Pendekatan lain baik mengenai pengangguran kaum muda atau NEET adalah peran pendidikan. Individu memperoleh sebagian besar human capitalnya dari sekolah, baik formal maupun non formal seperti pelatihan. Keahlian dan kemampuan atau human capital tersebut adalah modal memasuki pasar kerja (Borjas, 2016). Tingkatan pendidikan berhubungan tidak hanya dengan tingkat bekerja, tetapi juga tingkat pendapatan.

NEET digunakan dalam pembangunan ekonomi sebagai ukuran marginalisasi dan ketidakterlibatan kamu muda, dan dapat digunakan dalam menganalisa masalah pada pasar kerja kaum muda (Kovrova \& Lyon, 2013). Hubungan antara pertumbuhan ekonomi dan banyaknya kaum muda yang tidak bekerja adalah berbanding terbalik, terutama jika kaum muda sangat rentan, dan harus bersaing dengan pencari kerja 
profesional atau berpengalaman di pasar kerja kompetitif dengan penawaran pekerjaan terbatas (Bălan, 2015).

Menurut Martin (2009) dalam studinya mengenai pengangguran kaum muda, tingkat pengangguran pemuda relatif tinggi dibandingkan penduduk usia kerja lainnya dengan beberapa alasan. Pertama, di antara penduduk usia kerja, pemuda merupakan yang paling rentan jika terjadi economic downturn. Pekerja kaum muda memiliki pengalaman kerja lebih sedikit, dan tidak diutamakan dalam pelatihan di perusahaan, dan cenderung dipekerjakan dalam kontrak jangka pendek. Pada kondisi dimana perusahaan harus merumahkan pekerjanya, pekerja kaum muda adalah yang paling rentan untuk cenderung tidak dipekerjakan lagi.

Kedua, bagaimanapun kondisi ekonomi, kaum muda memiliki pengalaman yang minim dalam mencari atau mendapatkan pekerjaan. Kurang pengalaman dalam bekerja berhubungan dengan pemuda yang bekerja dengan upah yang kecil. Ketiga, pemuda, dengan keterbatasan sumber daya dan ketergantungan secara finansial kepada keluarga, sehingga kaum muda cenderung kurang mobile sehingga kurang mampu untuk pindah ke tempat dengan peluang pekerjaan yang lebih besar.

Keempat, kaum muda yang hidup dengan tanggungan keluarga dan tanpa beban untuk kewajiban finansial, cenderung tidak serius untuk mencari pekerjaan. Terutama pada keluarga dengan ukuran keluarga yang kecil dan tidak ada tekanan untuk bekerja menopang keluarga. Akibatnya, kaum muda tersebut akan menunda hingga mendapat pekerjaan yang tepat hingga beberapa waktu tertentu hingga mendapatkan upah yang sesuai dengan reservation wage-nya.

\section{METODE PENELITIAN}

Indikator yang digunakan dalam penelitian ini antara lain tingkat pengangguran terbuka kaum muda, employment rate, dan NEET. Data yang digunakan adalah dari Survei Angkatan Kerja Nasional (SAKERNAS) Agustus 2018. Tingkat pengangguran terbuka kaum muda dihitung dari penduduk berusia 15 sampai 24 tahun yang menganggur terhadap penduduk angkatan kerja baik yang bekerja maupun yang tidak bekerja. Seseorang dianggap menganggur jika tidak bekerja tetapi sedang mencari pekerjaan, sedang mempersiapkan usaha, sudah diterima bekerja atau mempunyai usaha tetapi belum mulai.

Seseorang dianggap bekerja jika melakukan suatu kegiatan dengan tujuan memperoleh penghasilan atau keuntungan paling sedikit selama satu jam (tidak terputus) dalam periode yaitu seminggu yang lalu. Termasuk didalamnya mereka yang memiliki pekerjaan/usaha tetapi selama seminggu yang lalu tidak bekerja karena sesuatu sebab seperti sakit, atau cuti. Employment rate kaum muda juga dihitung pada usia 15-24 tahun, yaitu kaum muda yang bekerja dibagi dengan angkatan kerja. Indikator terakhir adalah NEET, yang berarti penduduk usia 15-24 tahun yang tidak bekerja, tidak dalam pendidikan (sekolah), dan tidak dalam pelatihan. Pada indikator ini termasuk penduduk dalam angkatan kerja maupun bukan angkatan kerja.

Penelitian ini menggunakan data sekunder cross section yaitu data Survei Angkatan Tenaga Kerja Nasional (SAKERNAS 2018) di Indonesia. Metode analisis yang digunakan adalah logistik biner. Nachrowi \& Usman (2008) menyebutkan bahwa dalam model regresi logistik dikotomi, variabel terikat dinyatakan dengan fungsi logit untuk $\mathrm{Y}=1$ 
dibandingkan dengan fungsi logit untuk $Y=0$. Dalam penelitian ini, variabel terikat adalah kaum muda yang dikategorikan sebagai NEET $(Y=1)$ dan bukan NEET $(\mathrm{Y}=0)$. Metode estimasi yang digunakan adalah metode Maximum Likelihood. Adapun variabel bebas yang digunakan dalam penelitian ini antara lain pendidikan terakhir, umur, jenis kelamin, status perkawinan, tipe wilayah tempat tinggal dan status migran risen.

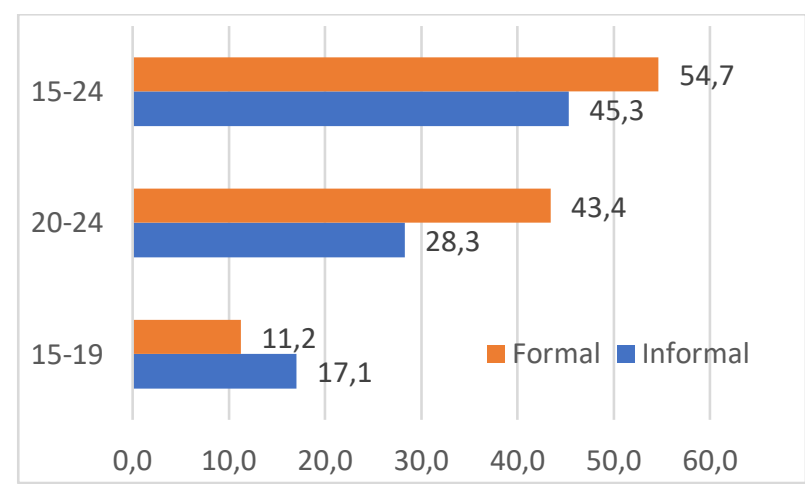

(a)

\section{HASIL DAN PEMBAHASAN}

Gambaran Umum Pekerja Muda

Jika dilihat dari status pekerjaan, kaum muda lebih banyak bekerja di sektor formal $(54,7$ persen) dibandingkan di sektor informal yang hanya sebesar 45,3 persen (Gambar 1.a). Kelompok pekerja usia remaja 15-19 tahun lebih banyak yang bekerja di sektor informal, dan sebaliknya kelompok pekerja usia yang 20-24 tahun lebih banyak bekerja di sektor formal.

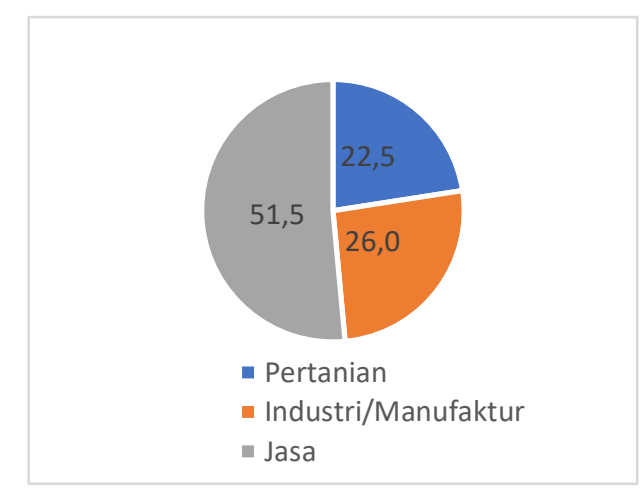

(b)

Gambar 1. Persentase Kaum Muda menurut Status Pekerjaan dan Lapangan Pekerjaan Utama, 2018

Sumber : SAKERNAS 2018, (Data diolah)

Hal ini dapat disebabkan kaum muda berusia 20-24 tahun sudah menyelesaikan sekolah menengah atas ataupun sudah pernah bekerja atau berpengalaman. Sementara pada kelompok usia yang lebih muda 15-19 tahun lebih rentan dan dihadapkan pada terbatasnya lapangan pekerjaan atau permintaan tenaga kerja pada usia tersebut.

Sektor informal masih menjadi solusi penyedia peluang pekerjaan bagi kaum muda yang masih belum berpengalaman atau pertama kali masuk pasar kerja. Dampak positif lain tersedianya pekerjaan di sektor informal bagi kaum muda adalah mengurangi tingkat pengangguran terbuka dan berkontribusi bagi ekonomi. Disisi lain, pekerjaan sektor informal identik dengan tingkat produktivitas yang rendah, pekerjaan kasar, skala kecil, tanpa jam kerja yang terbatas, keterampilan yang rendah, upah rendah dan tidak adanya jaminan kesehatan dan keselamatan kerja. Pekerja sektor informal bekerja pada kondisi sangat rentan pada resiko tinggi tanpa jaminan sosial. Kerentanan pada penyakit dan kesehatan yang buruk akibat lingkungan kerja yang tidak memenuhi standar harus dihindari terutama kaum muda yang bekerja di sektor informal.

Sementara itu, jika dilihat berdasarkan klasifikasi tiga lapangan pekerjaan utama 
(sektor pertanian, sektor industri, dan sektor jasa), maka proporsi pekerja kaum muda mendominasi pada sektor jasa yaitu sebesar 51,5 persen (Gambar 1(b)). Proporsi terendah adalah pada sektor pertanian dengan persentase 22.5 persen. Hal ini sejalan dengan transformasi struktural yang terjadi di Indonesia, dimana terjadi pergeseran dari pertanian ke sektor industri/manufaktur atau jasa.

Pengangguran Kaum Muda

Indikator penting yang perlu dianalisa mengenai masuknya kaum muda pada pasar kerja adalah tingkat pengangguran terbuka.
Tren pengangguran terbuka kaum muda di Indonesia sejak tahun 1989-2018 berfluktuasi dan mencapai puncaknya pada tahun 2005. Akan tetapi setelah tahun 2006 hingga tahun 2018, tren tingkat pengangguran terbuka kaum muda cenderung stagnan pada kisaran 19,4 - 25,1 persen (Gambar 2). Sementara itu, tren pengangguran terbuka (TPT) total memiliki pola yang sama dengan TPT kaum muda. Hal itu menunjukkan bahwa besarnya proporsi tingkat pengangguran kaum muda ikut menyumbang tingkat pengangguran terbuka total.

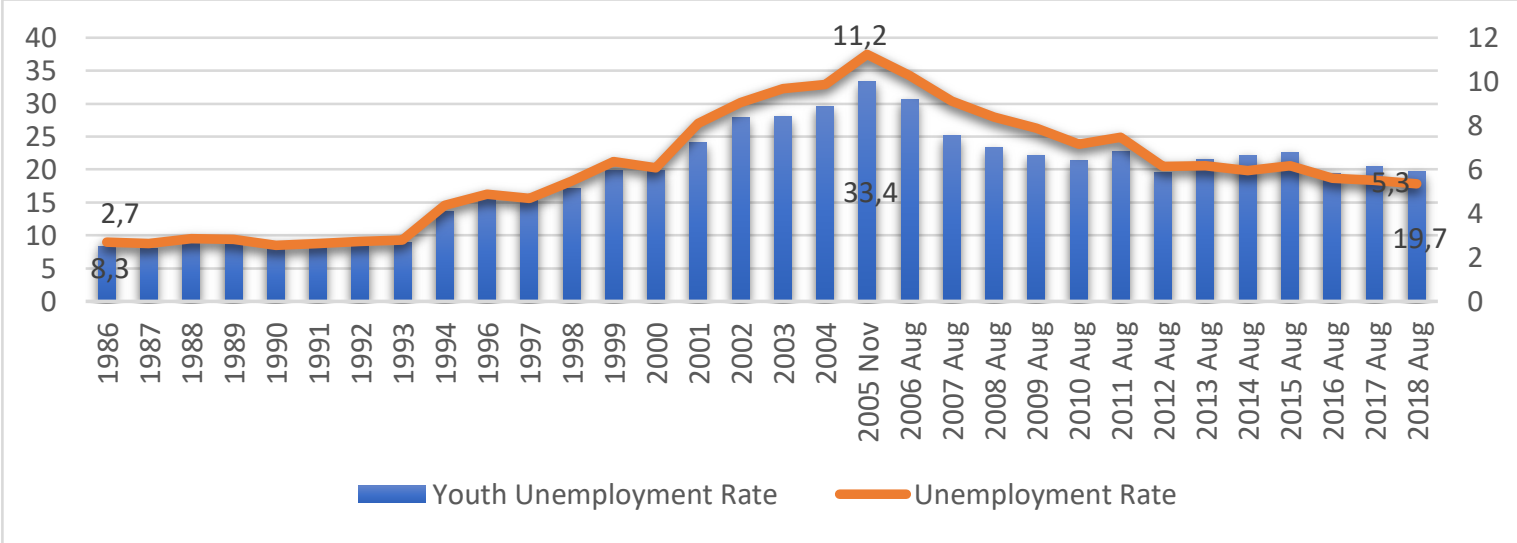

Gambar 2. Tren Tingkat Pengangguran Terbuka dan Tingkat Pengangguran Kaum Muda di Indonesia, 1989-2018.

Sumber: BPS, 2019 (Data diolah).

Seperti ditunjukkan Gambar 2, terjadi pundah tingkat pengangguran terbuka pada kaum muda. Menurut Adioetomo \& Indrayanti (2016) pada tahun 2005, terjadi puncak banyaknya lulusan SMA/SMK yang mencapai $30.6 \%$ dengan proporsi wanita lebih banyak dibandingkan dari laki-laki. Tingginya tingkat persentase lulusan SMA/SMK seharusnya memberikan harapan penyerapan tenaga kerja terdidik. Akibatnya, dengan supply tenaga kerja yang banyak tetapi tidak terserap di pasar kerja, tingkat pengangguran mencapai puncaknya pada tahun 2005.
NEET (Not in Employment, Education, or Training)

Lebih dari setengah kaum muda yang tidak bekerja, tidak bersekolah maupun tidak mengikuti pelatihan adalah perempuan, dan proporsi terbanyak pada perempuan berusia 20-24 tahun (Tabel 2). Banyaknya perempuan dalam kategori ini dapat disebabkan karena secara tradisional perempuan muda terlibat dalam pengurusan rumah tangga, mengasuh, atau melakukan pekerjaan sebagai pekerja keluarga yang tidak dibayar yang tidak dimasukkan ke dalam kategori bekerja. Alasan lain, 
perempuan kaum muda, terutama yang menikah dan bahkan sudah memiliki anak berusia 20-24 tahun merupakan usia sehingga tidak masuk ke pasar kerja. menikah sehingga perempuan ini sudah

Tabel 2.

NEET berdasarkan Jenis Kelamin dan Kelompok Umur, Indonesia 2018

\begin{tabular}{cccccc}
\hline & \multicolumn{2}{c}{ Laki-Laki } & \multicolumn{2}{c}{ Perempuan } & Jumlah Pemuda \\
\cline { 2 - 6 } & $15-19$ & $20-24$ & $15-19$ & $20-24$ & $15-19$ \\
\hline Jumlah NEET & 1.583 .550 & 2.065 .457 & 1.848 .379 & 4.217 .396 & 9.714 .782 \\
\hline $\begin{array}{c}\text { \% NEET berdasaarkan } \\
\text { jumlah pemuda }\end{array}$ & 3,6 & 4,7 & 4,2 & 9,6 & 22,1 \\
\hline
\end{tabular}

Sumber: SAKERNAS 2018, (Data diolah).

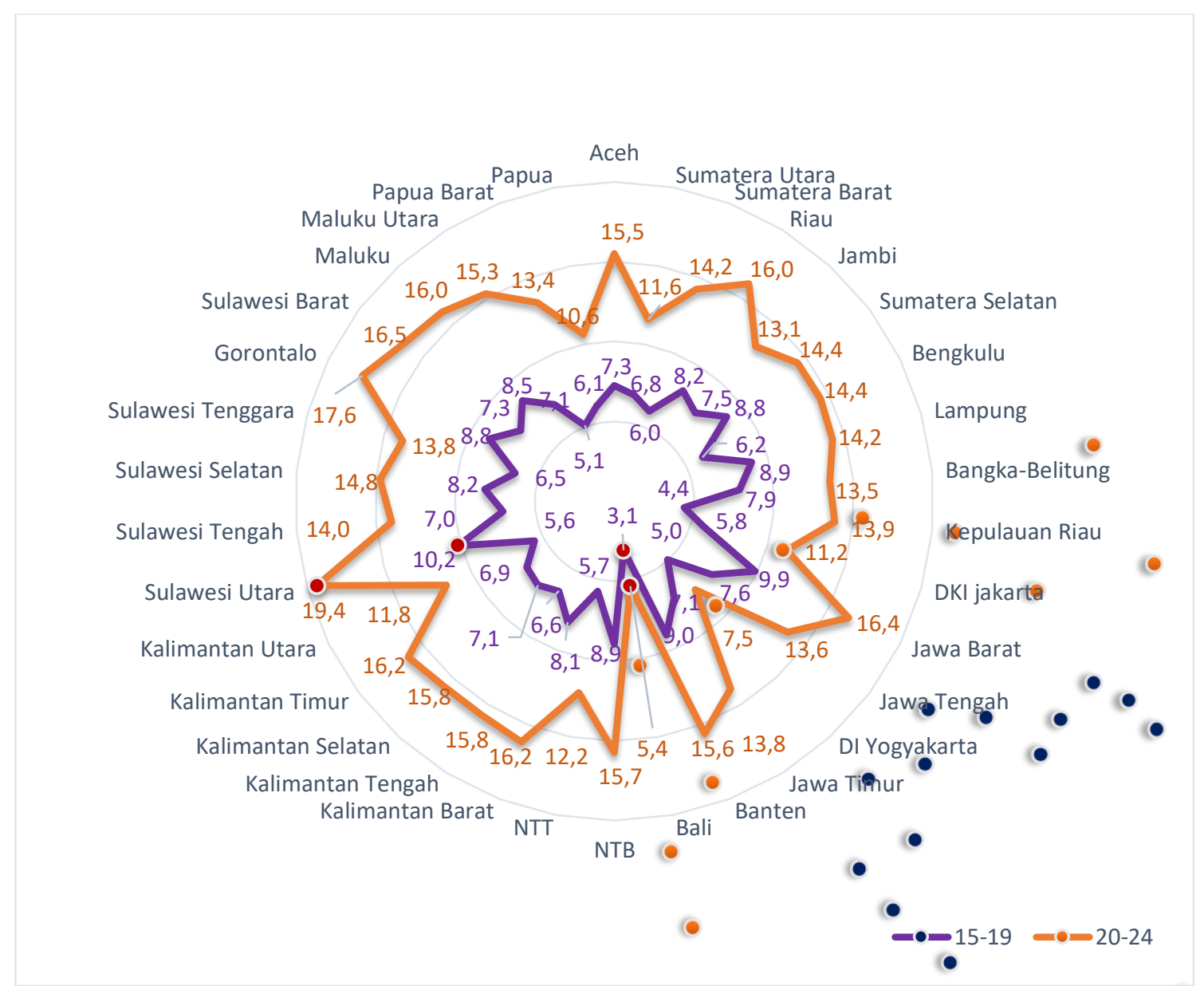

Gambar 3. Percentage of NEET by Province, 2018

Sumber: SAKERNAS 2018, (Data diolah).

Provinsi Bali memiliki persentase kaum muda yang tidak bekerja maupun dalam pendidikan yang terendah dibandingkan provinsi lain (Gambar 3). NEET Bali adalah $8.5 \%$ dengan $3.1 \%$ dari usia $15-19$ tahun dan
5.4\% dari usia 20-24 tahun. Hal ini disebabkan karena majunya sektor pariwisata di Bali sehingga menciptakan peluang kerja bagi kaum muda. Sementara itu, provinsi Sulawesi Utara merupakan 
provinsi paling menonjol dengan NEET komposisi 10.2\% dari usia 15-19 tahun dan tertinggi yaitu mencapai $29.6 \%$ dengan $19.4 \%$ dari usia 20-24 tahun.

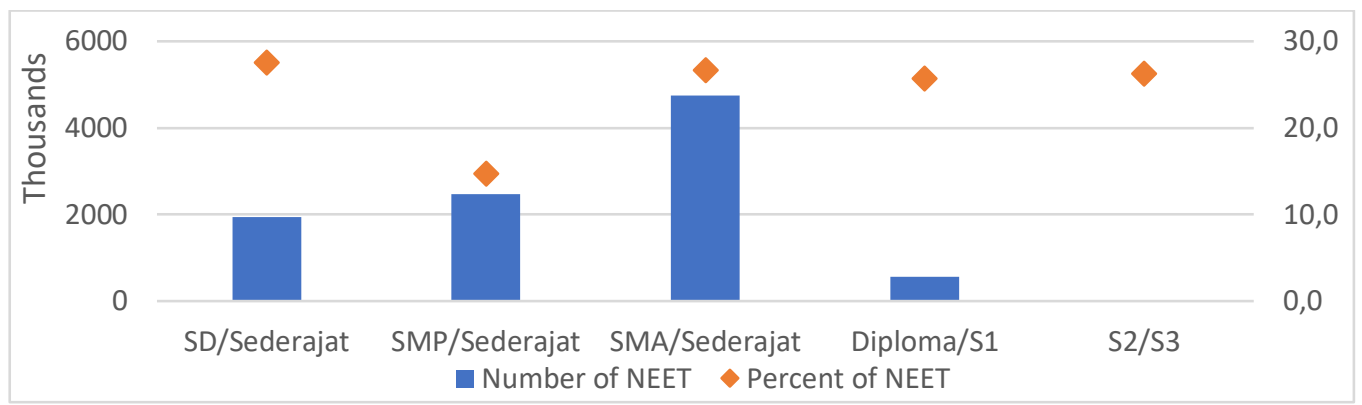

Gambar 4. Jumlah dan Proporsi NEET menurut Pendidikan yang Ditamatkan Indonesia 2018

Sumber: SAKERNAS 2018, (Data diolah).

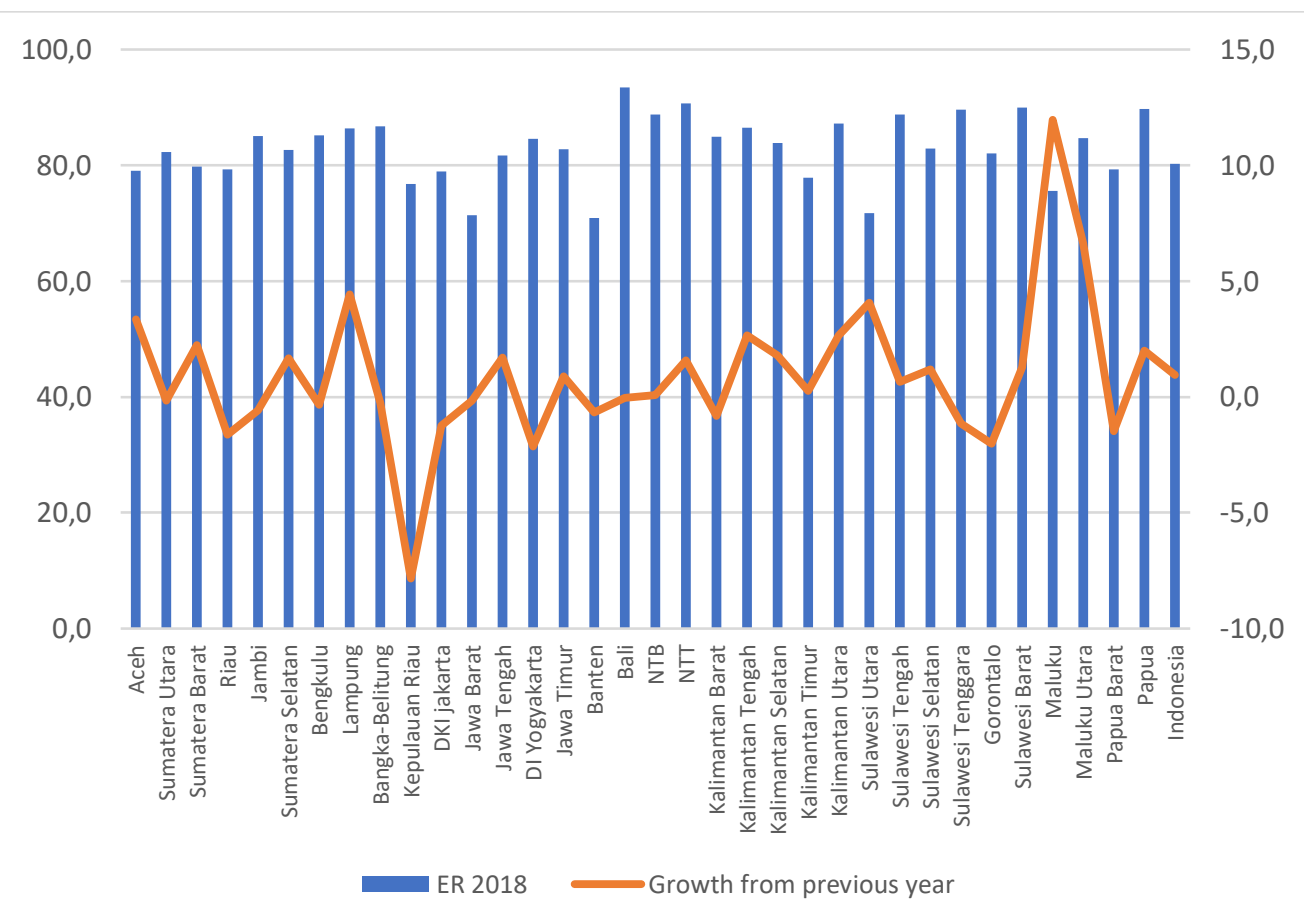

Gambar 5. Employment Rate of Youth \& Growth from Previous Year, Indonesia 2018 Sumber : SAKERNAS 2018, (Data diolah).

Berdasarkan tingkat pendidikan, proporsi terendah NEET nasional disumbang oleh pendidikan tertier S2/S3 (Gambar 4), yang dapat disebabkan oleh rendahnya angkatan kerja berusia 15-24 tahun dengan jenjang pendidikan tersebut dibandingkan lulusan tingkat pendidikan lain. Kendati demikian, proporsi NEET dari jenjang pendidikan tertinggi ini mencapai lebih dari seperempatnya, sekitar 3,257 kaum muda.
Proporsi tertinggi NEET adalah lulusan SMA/SMK atau sederajat yang mencapai sekitar 4,7 juta kaum muda atau 26,7 dari seluruh kaum muda lulusan tingkat pendidikan SMA atau sederajat. Fenomena ini sejalan dengan tingginya pengangguran dari tingkat pendidikan SMA atau sederajat. Adanya penawaran tenaga kerja yang tidak terserap ini menunjukkan kelompok penganggur ini cenderung lebih memilih 
pekerjaan atau menunggu hingga penawaran pekerjaan dengan upah melebihi endowment point.

Secara umum, employment rate kaum muda menurut provinsi mengalami peningkatan, kecuali pada 13 provinsi dengan penurunan tertinggi di Kepulauan Riau sebesar 7,8 persen, dan DI Yogyakarta 2,2 persen, sisanya turun kurang dari 2 persen termasuk Papua Barat, DKI Jakarta, dan Gorontalo (Gambar 5).

\section{Determinan NEET}

Tabel 3 menunjukkan hasil dari regresi logistik biner dalam mengidentifikasi faktorfaktor yang mempengaruhi kaum muda sebagai NEET. Secara umum, semua variabel bebas (pendidikan terakhir, umur, jenis kelamin, status perkawinan, tipe wilayah tempat tinggal dan status migran risen) yang digunakan dalam penelitian ini signifikan secara statistik memengaruhi NEET dengan tingkat kepercayaan 95 persen $(\alpha=5 \%)$. Variabel pendidikan signifikan mempengaruhi kondisi kaum muda menjadi NEET. Dibandingkan dengan pendidikan SD atau sederajat, kecenderungan kaum muda dengan pendidikan SMP atau sederajat cenderung lebih kecil menjadi NEET (Odd Ratio=0,43). Sementara itu, kaum muda lulusan pendidikan SMA sederajat memiliki kecenderungan tertinggi menjadi NEET (Odd Ratio =1,25) dibandingkan jenjang pendidikan lain. Kaum muda dengan pendidikan perguruan tinggi memiliki kecenderungan 1.1 kali lebih tinggi menjadi NEET dibandingkan pendidikan dasar. Hal itu sejalan dengan penelitian dari Erdoğan et al. (2017) yang menemukan bahwa tingginya kecenderungan kaum muda menjadi NEET mencerminkan struktur dari pasar tenaga kerja yaitu mismatch antara keterampilan yang dipersiapkan oleh universitas dengan karakteristik pekerja pada perusahaan.

Dari jenis kelamin, kecenderungan wanita menjadi NEET lebih besar 74 persen dibandingkan laki-laki (Odd Ratio=1.74). Hal ini dikarenakan perempuan pada umumnya melakukan pekerjaan rumah tangga, termasuk menjaga anggota keluarga. Hasil ini sejalan dengan penelitian dari Khatun \& Saadat (2020) yang menemukan bahwa peluang perempuan cenderung menjadi NEET $0.16 \%$ lebih tinggi dibandingkan laki-laki. Pattinasarany (2019) menemukan bahwa pekerjaan rumah tangga merupakan faktor yang penting dalam menahan perempuan muda untuk tetap dalam status NEET.

Berdasarkan variabel status perkawinan, kaum muda yang berstatus kawin cenderung 3,7 kali menjadi NEET dibandingkan kaum muda yang berstatus tidak kawin (Odd Ratio=3,68). Hal itu sejalan dengan penelitian Pattinasarany mengenai NEET di Indonesia tahun 2015 yang menemukan bahwa laki-laki yang berstatus kawin 17.1 persen cenderung lebih rendah menjadi NEET dibandingkan wanita berstatus kawin karena terlibat dalam kewajiban rumah tangga.

Jika dilihat dari kelompok umur, kecenderungan pemuda berusia 20-24 tahun menjadi NEET 18 persen lebih besar dibandingkan kaum muda pada kelompok umur yang lebih muda, yaitu 15-19 tahun (Odd Ratio=1,18). Penduduk kelompok remaja atau di bawah 20 tahun, sebagian besar masih bersekolah dibandingkan penduduk yang lebih tua. 
Tabel 3.

Hasil Regresi Logistik Biner Determinan NEET

\begin{tabular}{|c|c|c|c|}
\hline Karakteristik & Koefisien & Odds Ratio & Sig \\
\hline \multicolumn{4}{|l|}{ Pendidikan } \\
\hline \multicolumn{4}{|l|}{ SD (ref.) } \\
\hline SMP sederajat & -0.84378 & 0.4300825 & 0.000 \\
\hline SMA sederajat & 0.224735 & 1.251991 & 0.000 \\
\hline Perguruan Tinggi & 0.109784 & 1.116037 & 0.009 \\
\hline \multicolumn{4}{|l|}{ Jenis Kelamin } \\
\hline \multicolumn{4}{|l|}{ Laki-laki (ref.) } \\
\hline Perempuan & 0.552731 & 1.737993 & 0.000 \\
\hline \multicolumn{4}{|l|}{ Kelompok Umur } \\
\hline \multicolumn{4}{|l|}{ 15-19 (ref.) } \\
\hline $20-24$ & 0.164782 & 1.179135 & 0.000 \\
\hline \multicolumn{4}{|l|}{ Status Perkawinan } \\
\hline \multicolumn{4}{|l|}{ Tidak Kawin (ref.) } \\
\hline Kawin & 1.303238 & 3.681198 & 0.000 \\
\hline Cerai Hidup & 0.988031 & 2.685941 & 0.000 \\
\hline Cerai Mati & 0.560192 & 1.751009 & 0.052 \\
\hline \multicolumn{4}{|l|}{ Klasifikasi } \\
\hline \multicolumn{4}{|l|}{ Urban (ref.) } \\
\hline Rural & 0.132494 & 1.141672 & 0.000 \\
\hline \multicolumn{4}{|l|}{ Status Migrasi Risen } \\
\hline \multicolumn{4}{|l|}{ Migran (ref.) } \\
\hline Non migran & -0.09316 & 0.911052 & 0.018 \\
\hline Konstanta & -1.87464 & 0.1534098 & 0.000 \\
\hline
\end{tabular}

Sumber : SAKERNAS 2018, (Data diolah).

Di sisi lain, kaum muda yang tinggal di perdesaan lebih cenderung menjadi NEET dibandingkan yang tinggal di perkotaan. Hal itu ditunjukkan dengan nilai odds ratio sebesar 1,14. (Pattinasarany, 2019) mendapatkan hasil yang sejalan dalam penelitiannya, yaitu penduduk perkotaan kecenderungan lebih rendah 21 persen menjadi NEET dibandingkan pemuda perkotaan. Penelitian (Wickremeratne \& Dunusinghe, 2018) mengenai NEET di Srilanka menunjukkan hasil yang serupa, yaitu pemuda yang tinggal di perdesaan $35.5 \%$ berpeluang menjadi NEET dibandingkan pemuda perkotaan.
Kaum muda yang berstatus bukan migran memiliki kecenderungan lebih rendah, yaitu 0,9 kali sebagai NEET dibandingkan pemuda migran. Hasil ini sejalan dengan penelitian (Eurofound, 2012) yang menemukan bahwa status migran meningkatkan kecenderungan menjadi NEET dibandingkan kaum muda yang bukan migran.

\section{SIMPULAN}

Selama 10 tahun terakhir, 2008-2018, tren tingkat pengangguran kaum muda (1524 tahun) cenderung stagnan dan berada pada kisaran 19,4 hingga 23,3 persen. Persentase kaum muda yang menjadi NEET 
tahun 2018 sebesar 22,1 persen yang mana didominasi oleh perempuan sebesar 13,8 persen. Provinsi Sulawesi Utara merupakan provinsi dengan persentase NEET terbesar pada tahun 2018 .

Kaum muda pada kelompok usia 20-14 tahun memiliki kecenderungan lebih besar untuk menjadi NEET dibandingkan kelompok umur 15-19 tahun. Dari segi pendidikan yang ditamatkan, kaum muda dengan pendidikan SMA/sederajat cenderung lebih besar untuk menjadi NEET, akan tetapi kecenderungan kaum muda dengan pendidikan perguruan tinggi tidak sebesar lulusan SMA/sederajat. Kaum muda berjenis kelamin perempuan, tinggal di perdesaan dan berstatus kawin meningkatkan kecenderungan untuk menjadi NEET. Temuan lain dari penelitian ini adalah pengaruh migrasi risen pada kecenderungan untuk menjadi NEET.

Melihat gambaran umum dan determinan NEET, maka terdapat beberapa kebijakan yang dapat diambil untuk menurunkan persentase NEET. Pertama, menciptakan kurikulum pendidikan terutama pada jejang SMK yang sesuai dengan ketersediaan pasar kerja. Kedua, pemerataan sarana pendidikan sehingga mudah diakses oleh pelajar di seluruh Indonesia termasuk di daerah terpencil. Ketiga, menyediakan dan mempermudah akses pelatihan dan pengembangan ketrampilan di seluruh wilayah sehingga kaum muda tidak melakukan migrasi ke tempat lain dan dapat memajukan daerah asalnya.

\section{DAFTAR PUSTAKA}

Adioetomo, S., \& Indrayanti, R. (2016). Memasuki Dunia Kerja dan Kondisi Ketenagakerjaan di Indonesia. In Memetik Bonus Demografi; Membangun Manusia Sejak Dini (pp. 153-179).

Bălan, M. (2015). Methods to Estimate the Structure and Size of the "Neet" Youth. Procedia Economics and Finance, 32(15), 119-124. https://doi.org/10.1016/s22125671(15)01372-6

Borjas, G. J. (2016). Labor Economics, Seventh Edition.

BPS. (2013). Proyeksi Penduduk Indonesia Indonesia 2010-2035. In Bulletin of Experimental Biology and Medicine (Vol. 90). https://doi.org/10.1007/BF00830441

Erdoğan, E., Yentürk, N., Akyüz, A. A., Kurtaran, Y., Yurttagüler, L., Dursun, K., \& Oy, B. (2017). Being a NEET in Turkey: Determinants and Consequences. (30).

Eurofound. (2012). NEETs - Young people not in employment, education or training: Characteristics, costs and policy responses in Europe. In European Foundation for the Improvement of Living and Working Conditions. https://doi.org/10.2806/41578

Feng, Z., Everington, D., Ralston, K., Dibben, C., Raab, G., \& Graham, E. (2015). Consequences, risk factors, and geography of young people not in education, employment or training (NEET). In The Scottish Govenrment Social Reseacrh.

ILO. (2017a). Global Employment Trends for Youth 2017. In International Labour Office. https://doi.org/9789221301080

ILO. (2017b). Indonesia Jobs Outlook 2017: Harnessing technology for growth and job creation. In LinkedIn. Retrieved from https://www.ilo.org/wcmsp5/groups/public/--asia/---ro-bangkok/---ilo-jakarta/documents/publication/wcms_613628.pdf 
Khatun, F., \& Saadat, S. Y. (2020). Youth Employment in Bangladesh. In Youth Employment in Bangladesh. https://doi.org/10.1007/978-981-15-1750-1

Kovrova, I., \& Lyon, S. (2013). NEET youth dynamics in Indonesia and Brazil : A cohort analysis March 2013 A cohort analysis. Understanding Children's Work Programme Working Paper Series, (March), 1-22.

Martin, G. (2009). A portrait of the youth labor market in 13 countries, 1980-2007. Monthly Labor Review, 132(7), 3-21.

Nachrowi, D., \& Usman, H. (2008). Penggunaan Teknik Ekonometri. Jakarta: PT. Raja Grafindo Persada.

Pattinasarany, I. R. I. (2019). Tolerance education in the hidden curriculum : A case study on Indonesian public school. MASYARAKAT Jurnal Sosiologi, 23(1), 1-30. https://doi.org/10.7454/M

Vasile, V. (2011). Youths on labour market.Features. Particularities. Pro-mobility factors for graduates. Elements of a balanced policy for labour migration. Revista Romana de Economie, 32(1), 97-123.

Wickremeratne, N., \& Dunusinghe, P. (2018). Youth Not in Education, Employment and Training (NEET) in Sri Lanka. Advances in Economics and Business, 6(5), 339-352. https://doi.org/10.13189/aeb.2018.060508 